\section{Environmental management control systems for carbon emissions}

Environmental management control systems

Nadia Di Giacomo Bologna University, Bologna, Italy

James Guthrie

Department of Accounting and Governance, Macquarie University, Sydney, Australia and Bologna University, Bologna, Italy, and

Federica Farneti

Department of Sociology and Business Law, Bologna University, Bologna, Italy

\begin{abstract}
Purpose - This paper aims to focus on a global consulting company and examine how it struggled to establish an effective environmental management control system for carbon emissions for its employees' air travel. The organisation was motivated to reduce its carbon emissions both to comply with regulation and to enhance or maintain corporate reputation.

Design/methodology/approach - The paper takes a case study approach, examining internal and external documents as well as conducting interviews with senior staff.

Findings - The case study investigates how Beta's management implemented a system to reduce carbon emissions. The organisation focused on air travel, but the study finds that employee travel preferences did not radically change. Rather than reduction in carbon emissions, as planned by head office, air travel carbon emissions actually increased during the period, and, as a consequence, the reported reduction targets were significantly adjusted downwards to meet the new realities.

Practical/implications - The study has implications for both policy and practice for organisations seeking to improve their sustainability performance.

Originality/value - The study responds to calls in the literature to undertake research to identify how management practices might reduce negative sustainability impacts, as there is little evidence of what management practices and accounting tools are being adopted, particularly in relation to carbon emissions from air travel. The paper adds to the creation of new accounting, giving visibility to carbon emission management through case study analysis.
\end{abstract}

Keywords Sustainability, Carbon emissions, Accounting tools, Air travel,

Sustainability management

Paper type Case study

(C) Nadia Di Giacomo, James Guthrie and Federica Farneti. Published in the PSU Research Review: An International Journal. This article is published under the Creative Commons Attribution (CC BY 4.0) licence. Anyone may reproduce, distribute, translate and create derivative works of this article (for both commercial and non-commercial purposes), subject to full attribution to the original publication and authors. The full terms of this licence may be seen at http://creativecommons.org/licences/by/4.0/legalcode 


\section{PRR \\ 1,1}

\section{Introduction}

An increasing number of global companies are building commitment to sustainability (Gray and Laughlin, 2012; Mio and Venturelli, 2013; Mio et al., 2015) and attempting to implement programmes and measures that will have less negative impact on the environment (Gray et al., 2014; Dumay et al., 2010), with the ultimate aim of addressing climate change (Okereke, 2007).

This paper considers management action to reduce carbon emission in a global organisation (Lane, 2010) and to observe how this company is responding to different pressures in this direction (Sullivan, 2009). Emission reduction is one of the range of activities aimed at addressing climate change (Sullivan and Gouldson, 2015, forthcoming). Our paper takes a case study approach to explore management action to reduce the carbon emissions associated with air travel by employees, outlining how managerial practices inside the organisation affect the organisation's environmental impact and how an organisation may enable change (Fraser, 2012). In terms of our case study of an environmental control system (EMCS) for reducing carbon emission, our research question is:

RQ1. Can management and accounting practices decrease an organisation's environmental impacts?

Company Beta, based in London, developed a travel project to reduce carbon emissions caused mainly by air travel by 25 per cent during a financial year (FY). The case study follows the attempts of Company Beta's management to reduce carbon emissions via the introduction of an internal EMCS. It finds that the organisation's stated aim to reduce voluntary air travel was not met. Although the company developed a strategy for managing and accounting for carbon emission reduction, using incentives for voluntary emission reduction, travel activity by the most frequent travellers within the organisation did not change, and the planned reductions were not achieved. This analysis compares two FY periods (FY1 and FY2) to establish whether management incentives influenced travellers and therefore a reduction in carbon emissions.

The paper proceeds as follows. Section 2 provides motivations for undertaking this study and briefly examines the related contextual literature. Section 3 introduces the research method and the research site. Section 4 presents the analysis of data and findings. Section 5 concludes and provides policy implications, in terms of risks and opportunities.

\section{Background and motivation}

There are calls in the literature to undertake research to identify how management practices might reduce negative sustainability impacts (Lee, 2009). However, there is little evidence of what management practices and accounting tools are being adopted, particularly in relation to carbon emissions from air travel. This paper attempts to respond to Lee's (2009, p. 1101) call and adds to the creation of new accounting, giving visibility to carbon emission management through case study analysis.

Milne and Grubnic (2011, p. 968) stated that there is:

[...] an enormous challenge and opportunity to undertake urgent research into a wide range of accounting and auditing issues concerning climate change, greenhouse gas (GHG) emission accounting, reporting and assurance, and emissions management and reduction.

Climate change and corporations' actions, or inactions, in relation to it have been widely discussed in the management and accounting literature (Bowen and Wittneben, 2011; Milne and Grubnic, 2011; Ascui and Lovell, 2011; Boston and Lempp, 2011; McNicholas and 
Windsor, 2011; Cooper and Pearce, 2011; Solomon et al., 2011; Kuo et al., 2012). As international debate about climate change and its impact continues, there is a view that acting in a more sustainable way by reducing carbon emissions is essential:

At the very heart of the response to climate change, however, lays the need to reduce emissions. In 2010, various governments agreed that emissions need to be reduced so that global temperature increases are limited to below 2 degrees Celsius (UFCCC, 2012, p. 1).

The motivations for business are not only altruistic but also legal (Wittneben and Kiyar, 2009). Bagur-Femenias and Llach (2013, p. 43) state that The reinforcement of environmental regulations worldwide in recent years has motivated firms to seek to adopt environmental management practices. For example, the National Greenhouse and Energy Reporting Act 2007 enacted by the Australian Government requires carbon emission information to be disclosed to government. Before 2013, carbon emission reporting was mainly undertaken on a voluntary basis (Evangelinos et al., 2015). From April 2013:

[... ] all businesses listed on the Main Market of the London Stock Exchange will have to report their levels of greenhouse gas emissions from the start of the next financial year under plans announced by the Deputy Prime Minister at the Rio+ 20 Summit (DEFRA, 2012, p. 1).

Global GHG emissions due to human activities have grown since pre-industrial times, with an increase of 70 per cent between 1970 and 2004. Carbon dioxide (carbon) is the most significant anthropogenic GHG. Its annual emissions increased by about 80 per cent between 1970 and 2004. The long-term trend of declining carbon emissions per unit of energy supplied reversed after 2000. Milne and Grubnic (2011, p. 951) highlight that Despite the growing tide of corporate activity on climate change no meaningful progress is being made on global GHG emissions reduction. One avenue for carbon emission reduction in corporations is a change in travel policy, with possible changes occurring in both amount of travel and adoption of carbon efficiency alternatives. For example, emissions from international aviation increased by almost 70 per cent between 1990 and 2002, according to the Commission of the European Union (McCarthy, 2010). The United Nations Intergovernmental Panel on Climate Change indicated that the impact of aircraft emissions on climate would be 2.6 to 11 times as large in 2050, as it was in 1992. McCarthy (2010, p. 1) states that:

[...] If, as many argue, GHG emissions must be reduced 50 to 80 per cent in that time period, emissions from aviation would need to be drastically reduced to provide a proportional share of the targeted reduction.

Milne and Grubnic (2011 p. 952) indicate that, for 2010-2029, Airbus forecasts that global air passenger growth rates will be 4.8 per cent per annum And that To meet a tripling of capacity, it anticipates an additional 25,000 aircraft. While fuel burn efficiency and aircraft loading rates have improved they have not kept up with capacity increases and nor are they anticipated to. Regardless of improved technology to produce more environmentally friendly aircraft, global air passenger growth rates will mean more carbon emissions.

Organisations are also motivated to manage their carbon emissions for reasons of credibility, reputation and branding. Prior literature suggests that decreasing of carbon emissions can both enable the implementation of a green agenda (Dwyer, 2009) and improve a company's image. Yu et al. (2009, p. 1065) state that being perceived as a green company may improve a company's image and reputation, thus attracting more talented workers and green-conscious customers. Strategic motivation has been recognised as a form of discriminatory element with respect to the quality of reports, especially in 
PRR

1,1

companies of considerable size (Mio, 2010) even if only a few businesses integrate climate change into their strategy (Amran et al, 2015).

While the calls for action in relation to climate change are many, there are few studies that examine the challenges and opportunities involved in management action within organisations to reduce carbon emissions. This motivates us to explore how a global company adapts, or otherwise, to climate change through changes in managerial action associated with individual employee air travel. The case study analysed highlights an attempt to decrease carbon emissions and provides an opportunity to examine the emergence of a new form of accounting.

\section{Research method and research site}

The case study method provides an understanding of a contemporary accounting phenomenon in an organisational setting (Stewart and Gapp, 2014). This method is suitable for the examination of a phenomenon in a particular context and makes possible the answering of questions of how and why in relation to what is happening within that organisation at a particular time. It emphasises detailed contextual analysis with reference to a limited number of events and their relationships. Yin (2003, p. 23) states:

$[\ldots]$ the case study research method is an empirical inquiry that investigates a contemporary phenomenon within its real-life context; when the boundaries between phenomenon and context are not clearly evident; and in which multiple sources of evidence are used.

This case study analyses how a large global company, Beta, attempted to reduce its carbon emissions and whether it was successful. Beta is one of the UK FTSE 100 companies and is regarded as an organisation that is proactive in relation to climate change and environmental issues. Companies from the UK FTSE represent significant entities in climate change governance both in terms of quantity of emissions as well as influence on international climate policy (Okereke, 2007, p. 477). One of the researchers worked at Beta for six months, and the company gave permission for her to undertake this research, including providing access to internal documents, employees and other material. Also, publicly available company reports were analysed and senior staff were interviewed, similar to previous research (Wittneben and Kiyar, 2009). The interviews were undertaken with a small number of air travellers in Beta to ascertain their views on management actions to reduce air travel and to establish their motivations for undertaking journeys by air. The internal and external documents, and the interviews, form the basis of the data for the research.

Beta is a global management consulting, technology services and outsourcing company, with more than a quarter of a million people serving clients in more than 120 countries. Through its corporate citizenship focus, it is committed to equipping its people around the world by 2015 with the management skills needed to achieve sustainability. The company generated net revenues of US\$25bn for FY1.

Table I illustrates several activities that affect Beta, as well as Beta's impact on the environment.

Beta has adopted a series of actions to foster environmental responsibility among employees, clients and suppliers. One of these is the Global Environmental Policy in which Beta states that it is committed to incorporating leading environmental practices into its business strategy and operations and to fostering environmental awareness and responsibility among its stakeholders. Another is its adoption and retention of Global ISO 14001 Certification. ISO 14001 is the internationally recognised standard for environmental management system (EMS), which supports organisations to 
demonstrate environmental commitment to their stakeholders - clients, employees, shareholders - while better managing environmental impact and risk. To obtain ISO 14001 certification, companies must identify significant impacts - such as carbon emissions, energy use and water consumption - and implement environmental management programmes to control and improve them. ISO 14001 means that a company's EMS is reviewed by external auditors and if compliant with the requirements of the ISO 14001:2004 standard, the company will receive certification. Beta achieved Global ISO 14001 certification, thus promoting EMS operations globally. A further action to foster environmental responsibility is the aim of achieving environmental targets.

Beta's progress against environmental targets for FY1 are highlighted in Figure 1. This study focuses on two targets indicated in Figure 1 in terms of carbon emission disclosure: reduce carbon emissions per employee by 40 per cent (Global Target) and 40 per cent in the UK.

To achieve its goal of reducing carbon emissions from air travel, as outlined in Figure 1, Beta established a management and accounting travel project. In introducing the project, Beta management stated on its website:

Business travel and energy use make up the majority of our footprint. We are minimising by finding cost and energy efficient solutions that meet the demand of business. In FY1 we reduced our per employee carbon emissions by approximately 30 per cent from our fiscal 2007 baseline.

However, air travel increased over the same period and in its FY2 annual report Beta stated:

The strong increase in demand for our services and our expansion into emerging growth markets over the past year resulted in an associated increase in air travel, which has slowed our progress toward our goal of reducing per employee carbon emission 40 per cent by FY2 from our fiscal 2007 baseline. As a result, we are updating our FY2 goal: we will continue to maintain a per employee carbon reduction of approximately 30 per cent against our fiscal 2007 baseline.

From this statement, we can observe that the company's attempt to reduce carbon emission was not achievable so it was forced to review and lower its carbon emission goal per employee in FY2.

To achieve this aim, during FY1, Beta reviewed its environmental target and a general 40 per cent target reduction in carbon emissions was set, with respect to the baseline in 2007. The carbon emissions of the London office in FY1 were the result of utilities (25 per cent) and travel (75 per cent), with 51 per cent generated by air travel (Figure 2).

\begin{tabular}{|c|c|c|}
\hline Work activity & Environmental aspect & Environmental impact \\
\hline Printing & Paper consumption & Depletion of natural resources \\
\hline \multirow[t]{2}{*}{ Leaving lights/computer on } & Energy consumption & Depletion of natural resources \\
\hline & Increase in $\mathrm{CO}_{2}$ emissions & Contribution to climate change \\
\hline \multirow[t]{2}{*}{ Travel } & Energy consumption & Depletion of natural resources \\
\hline & Increase in $\mathrm{CO}_{2}$ emissions & Contribution to climate change \\
\hline Waste generation & $\begin{array}{l}\text { Generation, storage and disposal } \\
\text { of general waste }\end{array}$ & $\begin{array}{l}\text { Waste to landfill sites } \\
\text { Hazardous waste }\end{array}$ \\
\hline $\begin{array}{l}\text { Catering/maintenance: } \\
\text { potential spills and leaks }\end{array}$ & Cleaning/other chemicals & $\begin{array}{l}\text { Emissions to water/natural } \\
\text { environment }\end{array}$ \\
\hline
\end{tabular}

Source: Beta (FY1 internal report), Beta's Environmental Programme Overview, p. 6

Environmental management control systems $-$ 


\section{PRR}

1,1

Figure 1.

Progress against environmental target

\section{Figure 2.}

Carbon emissions breakdown FY1 for Beta

\begin{tabular}{|c|c|c|c|c|}
\hline Target & FY0 actual & FY1 actual & $\begin{array}{l}\text { outcome }(\%) \\
\text { compared to } \\
\text { FY0 }\end{array}$ & Status \\
\hline $\begin{array}{l}\text { Reduce electricity consumption by } \\
\qquad 1 \% \text { per } \mathrm{m}^{2}\end{array}$ & $198 \mathrm{kWh}$ per M2 & $\begin{array}{l}189 \mathrm{kWh} \text { per } \\
\mathrm{M} 2\end{array}$ & $-4 \%$ & $\square$ \\
\hline $\begin{array}{c}\text { Decrease waste sent to landfill by } \\
10 \% \text { per person }\end{array}$ & $18.8 \mathrm{kgs} \mathrm{pp}$ & $10.9 \mathrm{kgs} \mathrm{pp}$ & $-42 \%$ & $\nabla$ \\
\hline Increase recycling rate to $42 \%$ & $42 \%$ & $52.3 \%$ & $+13 \%$ & $\nabla$ \\
\hline $\begin{array}{l}\text { Reduce paper consumption by } 5 \% \\
\text { per person }\end{array}$ & $6.21 \mathrm{Kg} \mathrm{pp}$ & $5.7 \mathrm{~kg} \mathrm{pp}$ & $-8 \%$ & $\nabla$ \\
\hline $\begin{array}{l}\text { Reduce travel carbon emissions (per } \\
\text { person) from flights compared to } \\
\text { predicted FY1 levels by } 6 \%\end{array}$ & $1.47 \mathrm{~T} \mathrm{CO} 2 \mathrm{pp}$ & $1.51 \mathrm{~T} \mathrm{CO} 2 \mathrm{pp}$ & $+2.72 \%$ & $\nabla$ \\
\hline $\begin{array}{c}\text { Reduce carbon emissions per } \\
\text { employee by } 40 \% \text { (Global Target) } \\
\text { UKI }\end{array}$ & $2.66 \mathrm{~T}$ & $2.62 \mathrm{~T}$ & $(\mathrm{~N} / \mathrm{A})$ & $\square$ \\
\hline
\end{tabular}

Source: Beta (FY1 internal report), Beta's Environmental Programme Overview, p. 7

\section{Carbon Emissions breakdown FY10}

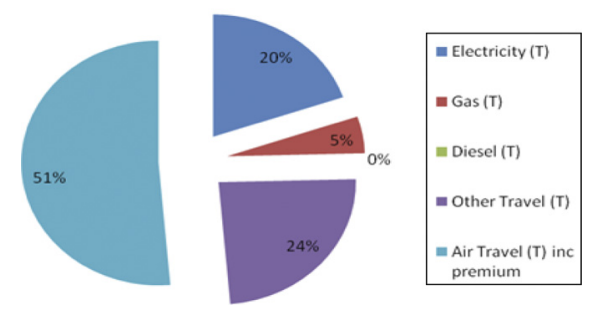

\section{Results of the case study}

As the company considered air travel the major contributor to carbon emissions in FY1, it focussed on reduction of air travel in its environmental target setting. To achieve the carbon emissions target set by the New York head office, Beta air travel would have to be reduced by 50 per cent. However, Beta set FY2 targets at a 25 per cent reduction in air travel compared to FY1. Achieving a reduction of 25 per cent in air travel would significantly reduce the company's carbon emissions, which would assist in progressing towards the global target of 40 per cent. Furthermore, this reduction also would deliver a saving of up to $£ 5.5$ million over the course of a 12 -month period:

Okereke (2007, p. 476) states that corporate actions for climate change could be styled to respond to the wider concerns for the environment whilst at the same time serving the core interests of business. But, despite the appeal of the win-win philosophy there is still an 
underlying tension regarding the degree of compatibility between business interests and environmental concerns.

Data collection for the case study focussed on three aspects of Company Beta's approach to carbon emission reduction with the aim of answering the three research questions of our research. The data collection, involving analysis of internal and external documents and interviews with staff, is outlined in the following subsections. The research focussed on the actions taken by Company Beta to achieve the 25 per cent reduction in FY2 air travel against FY1 levels, and the internal project team used the following eight steps to establish on EMCS for carbon emissions from employee air travel:

(1) understand the most significant clients generating travel;

(2) identify the top 100 travellers in terms of carbon impact;

(3) produce individual traveller carbon impact statements for the top 100;

(4) identify the most significant travel routes in terms of carbon impact;

(5) work with top travellers to identify drivers for travel, best practice and solutions to reduce air journeys;

(6) introduce an incentive scheme to encourage travellers to "do the right thing";

(7) increase the awareness and use of existing technology; and

(8) improve the use of communications channels.

The steps involved first the identification of significant air travel generators. Second, the company's travel distribution impact was established. Third, a group of 100 people was identified as causing the most carbon emissions from air travel, based on flights in business and first class (the top 100)[1]. This was established by merging data from travel agency data and credit card data, and then carbon emissions were calculated based on miles flown, aircraft used, route taken and class of travel. Four, from a geographic point of view, Beta is organised in three geographic regions: North America, Europe, Middle East, Africa and Latin America and Asia Pacific.

Five, to understand why Beta personnel travel, we selected the reasons they fly: business development, client meetings, internal meetings, market development, personal, project fly back, recruiting and training or workshops. To know where Beta employees travel, we elected the destination countries to which they fly the most. These are domestic, continental and intercontinental destinations and, in particular, cities based in Europe, the USA, Asia, Africa, Latin America and within the UK. Interviews were used to ask each of the top 100 travellers questions about their travel habits.

Six, several incentive schemes were developed by Beta to reduce its carbon emissions, mostly focussed on staff policy for travel. The incentive schemes included in step seven were:

- Virtual technology: Investment in new and improved technological tools (including Telepresence, a video conferencing system) to be deployed in different locations to increase the use of virtual meetings, thus reducing the need to travel. This was scheduled starting from FY2.

- New travel policy: To test the impact of the new global travel policy on travellers, sinceFY1.

- Rail travel: To encourage the use of train instead of plane where possible, especially for routes inside the UK (i.e. from London to Edinburgh), since FY1.
Environmental management control systems 
PRR

1,1

46

The final step eight was to improve the use of communication channels: to influence travellers through a communication plan.

We compared FY1 and FY2 results to determine whether the management action and the EMCS were effective in influencing travellers. For FY2, the findings show a 26 per cent overall increase in carbon emissions across all business entities, specifically: for business process outsourcing, it increased by 20 per cent, technology 43 per cent, management consulting 39 per cent and enterprise 84 per cent.

Also, on examining the results, it was found that the organisational level that travels most is the senior executive level. The business entity that flies the most is technology. The majority of travel is non-chargeable, mainly for client meetings. Our interview data suggested that, despite management actions to use alternative technologies, 17 per cent of those interviewed were restricted by lack of availability of telepresence, otherwise they would have used this facility. Some support was expressed for using alternative technologies, with 13 per cent of the respondents indicating a strong interest in using more virtual technology and 8 per cent wanting to install a telepresence unit in their own home. However, 6 per cent of travellers responded that it was essential to have a face-to-face relationship with clients and business partners. Therefore, little reduction in travel would be achieved by provision of alternative technologies. This represents a barrier to reduction in travel by the use of alternative technologies.

The main destination regions were the USA, UK, India and South Africa and the top four destination cities are Chicago, Bangalore, Edinburgh and Johannesburg (Figure 3). These routes were analysed to establish:

(1) carbon emissions by level;

(2) carbon emissions by business entity;

(3) the main reason and client for non-chargeable travel; and

(4) the main client for chargeable travel.

Analysis of the Chicago route is a useful example.

We observe that 44 per cent of carbon emissions from UK air travel are the result of flights to Chicago. Also, as represented in Figure 4, $\mathrm{CO}_{2}$ emissions by level of employees in travel to Chicago the level that travels the most is manager (30 per cent) followed by consultant (26 per cent). The business entity that flies the most is technology (43 per cent), with 93 per cent of technology travel non-chargeable, as shown in Figure 4, mainly for

Figure 3.

Level of $\mathrm{CO}_{2}$ emissions by top destination from the UK for Beta employees

\section{$\mathrm{CO}_{2}$ emissions by top destination from UK}

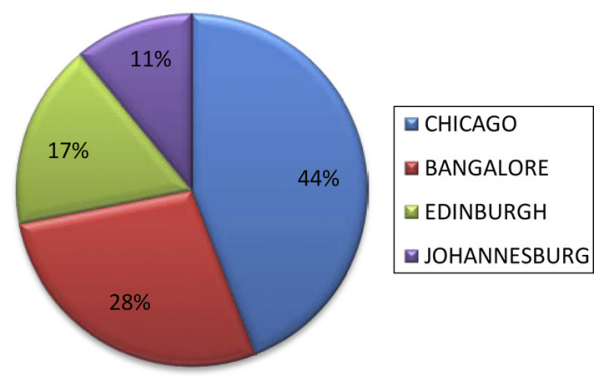


training (81 per cent) and all for internal project (100 per cent). Only 7 per cent is chargeable, mainly for internal project (44 per cent).

Despite evidence that Beta management attempted to reduce carbon by introducing incentives for voluntary emission reduction, in fact emissions increased. The company changed its target from 51 (originally) to 25 per cent. However, even the 25 per cent was not reached; rather, there was an increase of 26 per cent from FY1 to FY2. Doda et al. (2015, forthcoming) highlight that they find little evidence that management practices are actually reducing emissions.

\section{Conclusion}

The study examined how Beta attempted, unsuccessfully, to reduce carbon emissions by reducing air travel, given that is the main source of emissions during FY1-FY2. Although the London management company introduced a travel project and management actions in the form of incentives, these did not translate into actions by senior staff to reduce air travel.

The reason stated by Beta for the failure to meet its target was that there was an increase in workload. However, our interviews suggest that employees did not become sufficiently involved in the actions. While the travel project identified the who, why and how of travel, the individual behaviour within the organisation did not change as a result of management incentives, suggesting that the action of individual incentives is less likely to succeed than regulation. Alternative actions could include better availability of alternative technologies, a revised travel policy that emphasises alternative modes of travel, such as rail, and better marketing and communication of alternatives to air travel. Company Beta's approach to emission reduction focussed on changing individuals' behaviour rather than on organisational change.

For Company Beta, and organisations generally, there are risks and opportunities in their management of carbon emissions (Nelson et al., 2011). The possible risks include financial risks, where increased investment in new technology has no impact on travel, hence increasing costs for the company without any associated benefit. There are also business risks. If the company does not conform to government legislation and policies, it can lose its environmental certification and also its reputation as a sustainable organisation, which have been built up over many years of business. Operational risks may ensue if new technology is not used in an effective way, leading to a failure both from a technology point of view and for employees.

On the other hand, opportunities for Company Beta may be a decrease in costs if the implementation of new technology is effective in reducing air travel expenditure and an increase in the quality of work (and work environment) because of less travel. There is a

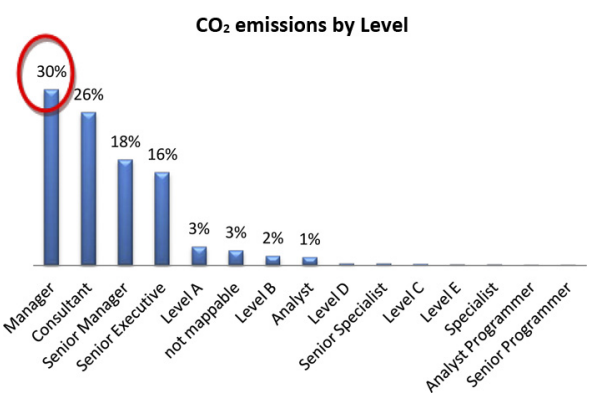

Figure 4. $\mathrm{CO}_{2}$ emissions by level of employee in Beta to Chicago 
PRR

1,1

potential enhancement to the organisation's reputation and therefore competitiveness. It may also improve its position in the market. Finally, there are potential improvements in operational effectiveness if new technology is used as an alternative to air travel, meaning an increase in the effectiveness of systems. In fact, a positive impact on the satisfaction of employees, in making them feel they work for an environmentally aware company (BagurFemenias and Llach, 2013).

Although the potential risks and opportunities outlined above are considered in the specific context of Company Beta, its experiences can inform policy in other organisations seeking to reduce carbon emissions. However, generalisability should be considered with caution because this study examines only one organisation over one year, focusing on one specific project and its attempts to reduce carbon emissions.

\section{Note}

1. Business and first class have been chosen because these discharge a greater amount of carbon due to the greater space available per traveller.

\section{References}

Amran, A., Ooi, S., Wong, C. and Hashim, F. (2015), "Business strategy for climate change: an ASEAN perspective", Corporate Social Responsibility and Environmental Management, doi: 10.1002/ ISSN.1535-3966.

Ascui, F. and Lovell, H. (2011), "As frames collide: making sense of carbon accounting”, Accounting Auditing \& Accountability Journal, Vol. 24 No. 8, pp. 978-999.

Bagur-Femenias, L. and Llach, J. (2013), "Is the adoption of environmental practices a strategical decision for small service companies? An empirical approach", Management Decision, Vol. 51 No. 1.

Boston, J. and Lem, F. (2011), "Explaining and solving the mismatch between scientific urgency and political inertia”, Accounting Auditing \& Accountability Journal, Vol. 24 No. 8, pp. 1000-1021.

Bowen, F. and Wittneben, B. (2011), "Carbon accounting. Negotiating accuracy consistency and certainty across organizational fields", Accounting Auditing \& Accountability Journal, Vol. 24 No. 8, pp. 1022-1036.

Cooper, S. and Pearce, G. (2011), "Climate change performance measurement control and accountability in English local authority areas", Accounting Auditing \& Accountability Journal, Vol. 24 No. 8, pp. 1097-1118.

Department for Environment Food \& Rural Affairs (DEFRA) (2012), "Leading businesses to disclose greenhouse gas emissions", available at: www.defra.gov.uk/news/2012/06/20/greenhouse-gasreporting/ (accessed 24 November 2012).

Doda, B., Gennaioli, C., Gouldson, A., Grover, D. and Sullivan, R. (2015), “Are corporate carbon management practices reducing corporate carbon emissions?", Corporate Social Responsibility and Environmental Management, available at: http://onlinelibrary.wiley.com/ journal/10.1002/

Dumay, J., Guthrie, J. and Farneti, F. (2010), "Contemporary international sustainability reporting guidelines for public and third sector organisations: a critical review", Public Management Review, Vol. 12 No. 4, pp. 531-548.

Dwyer, R. (2009), "Keen to be green organizations: a focused rules approach to accountability", Management Decision, Vol. 47 No. 7, pp. 1200-1216.

Evangelinos, K., Nikolaou, I. and Leal Filho, W. (2015), "The effects of climate change policy on the business community: a corporate environmental accounting perspective", Corporate Social 
Responsibility and Environmental Management, available at: http://onlinelibrary.wiley.com/ journal/10.1002/ISSN.1535-3966/earlyview

Fraser, M. (2012), "Fleshing out an engagement with a social accounting technology", Auditing \& Accountability Journal, Vol. 25 No. 3, pp. 508-534.

Gray, R. and Laughlin, R. (2012), "It was 20 years ago today: Sgt pepper, green accounting and the blue meanies", Accounting Auditing \& Accountability Journal, Vol. 25 No. 2, pp. 228-255.

Gray, R., Adams, C. and Owen, D. (2014), Accountability Social Responsibility and Sustainability. Accounting for Society and the Environment, Pearson.

Kuo, L., Yeh, C. and Yu, H. (2012), "Disclosure of corporate social responsibility and environmental management: evidence from China", Corporate Social Responsibility and Environmental Management, Vol. 19 No. 5, pp. 273-287.

Lane, J.E. (2010), "Economic catch-up and emission reductions", Sustainability Accounting Management and Policy Journal, Vol. 1 No. 1, pp. 96-102.

Lee, K.H. (2009), "Why and how to adopt green management into business organizations? The case study of Korean SMEs in manufacturing industry", Management Decision, Vol. 47 No. 7, pp. 1101-1121.

McCarthy, J. (2010), “Aviation and climate change”, available at: www.fas.org/sgp/crs/misc/R40090.pdf (accessed 13 October 2012).

McNicholas, P. and Windsor, C. (2011), "Can the financialised atmosphere be effectively regulated and accounted for?", Accounting Auditing \& Accountability Journal, Vol. 24 No. 8, pp. 1071-1096.

Milne, M. and Grubnic, S. (2011), "Climate change accounting research: keeping it interesting and different", Accounting Auditing \& Accountability Journal, Vol. 24 No. 8, pp. 948-977.

Mio, C. (2010), "Corporate social reporting in Italian multi-utility companies: an empirical analysis", Corporate Social Responsibility and Environmental Management, Vol. 17 No. 5, pp. 247-271.

Mio, C. and Venturelli, A. (2013), "Non-financial information about sustainable development and environmental policy in the annual reports of listed companies: evidence from Italy and the UK", Corporate Social Responsibility and Environmental Management, Vol. 20 No. 6, pp. 340-358.

Mio, C., Venturelli, A. and Leopizzi, R. (2015), "Management by objectives and corporate social responsibility disclosure. First results from Italy", Accounting Auditing \& Accountability Journal, Vol. 28 No. 3, pp. 325-364.

Nelson, T., Wood, E., Hunt, J. and Thurbon, C. (2011), "Improving Australian greenhouse gas reporting and financial analysis of carbon risk associated with investments", Sustainability Accounting Management and Policy Journal, Vol. 2 No. 1, pp. 147-157.

Okereke, C. (2007), "An exploration of motivations driver sand barriers to carbon management: the UK FTSE 100", European Management Journal, Vol. 25 No. 6, pp. 475-486.

Solomon, J.F., Solomon, A., Norton, S. and Joseph, N. (2011), "Private climate change reporting: an emerging discourse of risk and opportunity?", Accounting Auditing \& Accountability Journal, Vol. 24 No. 8, pp. 1119-1148.

Stewart, H. and Gapp, R. (2014), "Achieving effective sustainable management: a small-medium enterprise case study”, Corporate Social Responsibility and Environmental Management, Vol. 21 No. 1, pp. 52-64.

Sullivan, R. (2009), "The management of greenhouse gas emissions in large European companies", Corporate Social Responsibility and Environmental Management, Vol. 16 No. 6, pp. 301-309.

Sullivan, R. and Gouldson, A. (2015), "Comparing the climate change actions targets and performance of UK and US retailers", Corporate Social Responsibility and Environmental Management, available at: $\mathrm{http}: / /$ onlinelibrary.wiley.com/journal/10.1002/ISSN.1535-3966/earlyview

United Nations Framework Convention on Climate Change (UFCCC) (2012), "Background on the UNFCCC: the international response to climate change", available at: http://unfccc.int/ essential_background/items/6031.php (accessed 2 August 2012). 
PRR

1,1

50

\section{Further reading}

Bebbington, J., Unerman, J. and O'Dwyer, B. (2014), Sustainability Accounting and Accountability, Routledge.

\section{Corresponding author}

James Guthrie can be contacted at: james.guthrie@mq.edu.au

For instructions on how to order reprints of this article, please visit our website: 